\title{
IMPLEMENTASI STRATEGI SQ3R MEMBACA KRITIS SASTRA SISWA MI KELAS LANJUT
}

\author{
Dwi Masdi Widada \\ UIN Maliki Malang,widoke_11@yahoo.co.id
}

\begin{abstract}
ABSTRAK
Membaca pemahaman (kritis) merupakan salah satu tingkatan membaca yang memiliki strategi dalam pembelajaran bahasa Indonesia. Madrasah Ibtidaiyah adalah sekolah berbasis islam yang memiiki peluang untuk memelajari berbagai macam ilmu pengetahuan. Strategi SQ3R merupakan strategi pembelajarn membaca yang bertujuan untuk membantu pembaca agar dapat memahami secara utuh dan rinci tentang isi suatu teks. Siswa MI kelas lanjut memiliki kebebasan menganalisis dan mengapresiasikan beberapa karya seperti cerpen, puisi, dan drama dalam sudut pandang mereka. Membaca kritis memerlukan pemahamn subyektif yang harus dibina agar dapat memunculkan ide-ide kreativitas di kalangan siswa. Siswa Madrasah Ibtidaiyah memiliki keragaman tersendiri dalam berpikir sesuai dengan konteks nilai-nilai keislaman yang dimiliki.

Gambaran konkret mengenai penerapan strategi SQ3R ini akan disajikan contohcontoh panduan analisis kebutuhan pembelajaran dengan mengacu pada penerapan strategi SQ3R. Contoh penerapan tersebut akan disajikan pada tahap sebelum pelaksanaan pembelajaran dan saat pelaksanaan pembelajaran.
\end{abstract}

Kata Kunci: Membaca Kritis, Strategi SQ3R, Madrasah Ibtidiyah

\section{PENDAHULUAN}

Fungssi pembelajaran bahasa Indonesia di sekolah-sekolah termasuk Madrasah Ibtidaiyah, selanjutnya disingkat MI, adalah untuk meningkatkan kemampuan siswa dalam berkomunikasi. Komunikasi berbahasa Indonesia baik lisan maupun tulisan dapat menajamkan kemampuan di dalam mendapatkan wawasan atau informasi. Dengan kemampuan tersebut, siswa diharapkan mampu memahami informasi yang disampaikan. Adapun di dalam kurikulum 1994 SD 
dinyatakan bahwa fungsi pembelajaran bahasa Indonesia adalah sebagai sarana peningkatan pengetahuann dan keterampilan dalam rangka pelestarian dan pengembangan budaya, sebagai sarana peningkatan dan keterampilan untuk untuk meraih dan mengembangkan berbagai ilmu pengetahuan, teknologi, dan seni, sebagai sarana penyebarluasan pemakaian bahasa dan sastra Indonesia. Berbagai kemampuan yang diharapkan tersebut dapat dilatih pada siswa melalui empat aspek keterampilan berbahasa yaitu membaca, menyimak, berbicara, dan menulis.

Membaca merupakan salah satu aspek keterampilan berbahasa yang memiliki kedudukan penting dan strategis. Dikatakan demikian karena membaca merupakan bagian dari hidup manusia. Setiap aspek kehidupan ini keberadaannya tidak dapat dilepaskan dari respon berupa kegiatan membaca (Burns, 1996: 5). Semua yang ada di sekitar manusia (khususnya yang berbentuk tulisan) hanya dapat dipahami karena adanya proses membaca. Oleh karena itu, cukup beralasan apabila keterampilan membaca tidak hanya dibutuhkan oleh masyarakat akademis, tetapi juga diperlukan oleh siapa saja yang membutuhkan informasi. Sudah sewajarnya apabila membaca telah menjadi kebutuhan dan bagian dari gaya hidup masyarakat.

Membaca merupakan sebuatu bentuk keterampilan. Dalam konteks pembelajaran, siswa dikatakan terampil membaca apabila siswa dapat memahami makna yang terdapat di dalam bacaan. Untuk memenuhi hal tersebut, siswa harus dilatih membaca terus-menerus. Tentunya pelatihan membaca menggunakan strategi yang sesuai dengan kebutuhan siswa. Oleh karena itu, dalam pembelajarannya, guru harus mampu mengarahkan siswa agar dapat memilih dan menggunakan strategi membaca yang efektif dalam rangka memdapatkan pemahaman isi bacaan yang sedang dibaca.

Pembelajaran membaca di sekolah memiliki peran penting dalam membantu siswa agar terampil membaca. Terampil membaca bukan hanya sekadar membaca kata-kata, tetapi juga dapat membuat siswa menjadi mahir 
Dwi Masdi Widada, Implementasi Strategi SQ3R... (hlm. 323-339)

wacana (kemahirwacanaan), yakni mahir secara tekstual maupun kontekstual (Tompskin dan Hoskisson, 1991: 18). Siswa dikatakkan mahir membaca apabila mampu mencari, menyerap, dan menyeleksi informasi yang relevan secara tepat, mampu memanfaatkan kompetensi yang dimiliki tersebut dalam mendukung pandangan, merespon beragam teks dan menggunakannya untuk membuat intervensi dan deduksi.

Sehubungan dengan pembelajaran membaca kritis, guru harus mampu menerapkan strategi mengajar yang sesuai dengan kebutuhan siswa. Oleh karena itu, sebelum menentukan strategi pembelajara membaca, terlebih dahulu guru harus memahami tingkatan-tingkatan membaca pemahaman atau tipe-tipe pemahaman teks bacaan. Tipe-tipe pamahan tersebut antara lain: pemahaman literal, pemahaman interpretatif, pemahaman kritis, dan pemahaman kreatif. Keempat tipe tersebut saling berkaitan.

Membaca kritis merupakan salah satu tingkatan membaca yang memiliki kedudukan strategis dalam pembelajarn bahasa Indonesia (termasuk juga MI). membaca kritis perlu diajarkan kepada siswa karena pada prinsipnya siswa tidak hanya ingin mengetahui apa yang dibaca, melainkan ingin mengetahui kebenaran suatu informasi yang ada pada teks bacaan. Membca kritis merupakan kegiatan mengevaluasi materi tertulis yakni membandingkan gagasan yang tercakup dalam materi dengan standar yang diketahui dan menyimpulkan tentang keakuratan atau kesesuian (Burns, 1996: 278). Pembaca kritis harus dapat menjadi pembaca yang aktif bertanya, meneliti fakta-fakta, mempertimbangkan semua isi materi. Membaca kritis merupakan kegiatan yang dimulai dari kegiatan analisis, sintesis, dan evaluasi. Membaca kritis dapat dikatakan sebagai membaca analisis dan evaluasi. Oleh karena itu, seorang pembaca kritis harus mampu memiliki pikiran yang tajam sehingga mampu bersikap kritis terhadap teks yang dibaca. 
Sampai saat ini kondisi objektif pembelajaran membaca sastra di lembaga pendidikan formal masih belum optimal. Dikatakan demikian karena pembelajaran membaca cerpen padaumumnya masih terbatas pada analisis struktur cerpen dengan menekankan pada kognitif sastra semata. Dalam hal ini, kegiatan yang dilakukan biasanya dimulai dengan kegiatan membaca dan diakhiri dengan menganalisis unsur intrinsik. Padahal kegiatan tersebut sebenarnya dapat diarahkan pada upaya melatih siswa untuk memberikan penilaian kritis dengan melibatkan berbagai kemampuan, kepekaan, dan emosi. Dengan perkataan lain, analisis struktur sastra yang selama ini diberlakukan dalam membaca sastrakurang memberikan kesempatan kepada siswa untuk berinteraksi dan mengakrabkan diri pada sastra, baik cerpen, puisi, mapun drama.

Pembelajaran membaca krisis sastra sanpai saat ini tampaknya belum optimal, baik ditinjau dari segi tahap perencanaan, tahap pelaksanaan, dan tahap evalusi pembelajaran. Pada tahap perencanaan, guru tampak masih mengalami kesulitan dalam menentukan materi yang menarik dan kesesuaian dengan tingkat kemampuan siswa. Guru umumnya mengambil materi pelajaran cerpen dari buku paket. Pada tahap pelaksanaan, guru seringkali menggunakan strategi pembelajaran membaca yang kurang tepat dan kurang bervariasi. Dalam hal ini, kegiatan guru biasanya sebatas pada memilih bahan cerpen dan menyuruh siswa untuk membacanya. Setelah membaca siswa disuruh menjawab pertanyaan yang berhubungan dengan cerpen tersebut. Ironisnya lagi, guru tidak membantu atau membimbing siswa dalam membaca saat kegiatan pembelajaran membaca berlangsung. Guru lebih sibuk dengan dirinya sendiri. Pada tahap evaluasi, guru hanya mengambil nilai dari hasil menjawab pertanyaan tanpa melihat proses membaca yang dilakukan siswa. Apabila kondisi tersebut terus berlanjut, maka siswa kurang terlatih untuk berpikir kritis karena kegiatan belajar-mengajar siswa hanya berkutat pada unsur-unsur literal. Kondisi seperti ini tentu memprihatinkan. Tidak ada nilai simpati dan empati. 
Dwi Masdi Widada, Implementasi Strategi SQ3R... (hlm. 323-339)

Bertumpu pada berbagai hal yang telah diuraikan di atas, sebaikny upaya untuk mengoptimalkan pembelajaran membaca kritis sastra, udah sepatutnya apabila praktik pembelajaran dilakukan dengan memanfaatkan berbagai strategi, tentunya strategi pembelajaran yang memungkinkan tercapainya tujuan pembelajaran yang diharapkan. Strategi yang dimaksud antara lain adalah strategi SQ3R. Agar diperoleh gambaran yang meyeluruh tentang permasalahan tentang permasalahan yang diajukan, maka dalam tulisan ini akan disajikan secara berturut-turut konsep-konsep tentang hakikat pembaca kristis, pembelajaran membaca pemahaman di Sekolah Dasar/Madrasah Ibtidaiyah, dan penerapan strategi SQ3R di MI kelas lanjut.

\section{Hakikat Membaca Kritis Sastra}

Aspek-aspek ketarampilan berbahasa di dalam pembelajaran bahasa dan sastra Indonesia dapat dilaksanakan secara terpadu. Pembelajaran keterampilan berbahasa membaca dapat dipadukan dengan keterampilan menyimak, berbicara, dan menulis. Dengan perkataan lain, di dalam setiap pembelajaran kbahasaan secara tidak langsung akan tercermin semua aspek ketarampilan berbahasa yang meliputinya, meskipun pelajarannyahanya difokuskan pada salah satu aspek. Selain itu, kterpaduan yang dimaksud bukan berarti bahwa semua komponen yang terdapat dalam setiap aspek keterampilan berbahasa tersebut harus ditonjolkan, tetapi salah satu komponen saja yang harus ditonjolkan.

Salah satu kegiatan pembelajaran yang terkait dengan komponen pemahaman adalah pembelajaran membaca. Membaca merupakan salah satu keterampilan berbahasa yang bersifat aktif-reseptif, yakni proses penyerapan informasi yang dilakukan secara aktif. Dikatakan aktif karena selain mengandalkan mata sebagai sarana utama dalam menerjemahkan lambanglambang huruf (tulisan). Proses membaca juga melibatkan berbagai piranti lainnya yang terdapat di dalam diri seseorang (seperti pengetahuan seseorang yang 
berhubungan dengan topik). Selain itu, pembca akan berupaya agar lambanglambang yang dilihatnya itu menjadi lambang-lambang yang bermakna baginya.

Membaca pada prinsipnya merupakan proses berpikir kontruktif yang mencakup pemahaman terhadap makna eksplisit dan implisit. Menurut Strauffer dn Walker, proses membaca di dalamnya melibatkan aplikasi, analisis, evaluasi, dan imajinasi (Pamfrey, 1977: 2). Berdasarkan pendapat tersebut, tampak bahwa membaca merupakan proses berpikir untuk mendapatkan pesan yang disampaikan penulis melalui tulisannya. Adapun untuk mendapatkan pesan dari bahan bacaan, seseorang diharapkan mampu membaca dengan baik sehingga pesan atau informasi yang disampaikan penulisnya dapat dipahami dengan baik pula. Keterampilan membaca bukan hanya merupakan salah satu ketrampilan dasar untuk menunjang keberhasilan dalam mengikuti pendidikan dan pengajaran di sekolah, melainkan juga merupakan ketarampilan yang sangat penting bagi setiap orang dalam kehidupan di masyarakat.

Kenyataan yang sering ditemukan dalam konteks pembelajaran membaca (diantaranya di MI kelas lanjut), biasanya siswa ditugasi untuk menjawab sebuah teks beberapa menit, selanjutnya siswa diminta untuk menjawab berbagai pertanyaan yang berhubungan dengan bacaan tersebut. Jadi, dalam hal ini kegiatan membaca tidak diawali dengan tahap prabaca atau tahap menggali skemata siswa, hanya mengutamakan kegiatan pascabaca yang diarahkan pada penilaian akhir pembelajaran. Kondisi seperti ini tentunya berimplikasi pada rendahnya tingkat kemampuan siswa dalam memahami isi bacaan. Sehubungan dengan hal ini, salah satu cara yang dapat ditempuh agar siswa dapat dengan mudah dalam memahami isi bacaan adalah dengan cara membangkitkan kembali pengalaman siswa yang berhubungan dengan topik bacaan. Pengalaman siswa yang berkaitan dengan isi bacaan dapat menentukan tingkat atau level pemahaman dalam membaca. Semakin banyak pengalaman siswa yang berkaitan dengan isi bacaan, maka akan semakin tinggi pula tingkat pemahaman dalam membacanya. 
Dwi Masdi Widada, Implementasi Strategi SQ3R... (hlm. 323-339)

Sehubungan dengan tingkat pemahamaan dalam membaca, Burns mnyatakan bahwa terdapat dua tipe pemahaman dalam membaca, yakni pemahaman tingkat dasar (literal comprehention) dan pemahaman tingkat tinggi (higher order comprehention). Membaca tingkat tinggi meliputi membaca interpretatif (interpretative reading), membaca kritis (critical reading), dan membaca kreatif (creative reading). Keberadaan kedua tipe membaca pemahaman tersebut saling berkaitan antara satu dengan yang lainnya. Karena kedua tipe tersebut merupakan dasar di dalam melaksanakan pembelajaran membaca pemahaman, maka guru harus memahaminya. Pemahaman literal menjadi dasar untuk pemaham yang lebih tinggi, begitu juga sebaliknya (Burns, 1996: 255).

Sehubungan dengan hal tersebut, perlu dipahami pula bahwa membaa pemahaman merupakan sebuah proses. Oleh karena itu, sebelum menentukan langkah-langkah proses pembelajaran membaca, guru seharusnya mengetahui dan memahami kondisi siswa (misalnya tingkat kecerdasan, kreatifitas, kondisi fisik, kebutuhan, dan perkembangan kognitif). Untuk mendorong siswa dalam membaca kritis, hendaknya para guru memerhatikan faktor-faktor yang berkaitan erat dengan kebutuhan siswa sehingga siswa akan melakukan proses membaca kritis dengan penuh kesungguhan.

Stern menyatakan bahwa pertumbuhan dan perkembahan manusia dapat diklasifikasikan atas aspek kognitif, psikologis, dan fiik. Adapun pertumbuhan dan perkembangan manusia tersebut berhubungan dengan perubahan struktur dan fungsi karakteristik manusia itu sendiri. Perubahan-perubahan tersebut terjadi dalam kemajuan yang mantap dan merupakan suatu proses kematangan. Perubahan tersebut tidak bersifat umum, melainkan merupakan hasil interaksi antar potensi bawahan dengan potensi lingkungan. Guru juga harus memahami kondisi tersebut (Mulyasa, 2004: 125).

http://journal.unesa.ac.id/index.php/paramasastra | 329 
Tantangan bagi pendidikan adalah mengupayakan bagaimana menemukan atau menciptakan metode pendidikan dan lingkungan-lingkungan yang sesuai dengan kebutuhan setiap siswa yang unik tersebut. Secara khusus apabila dikaitkan dengan konteks pembelajaran membaca kritis, penyebab timbulnya permasalahan yang dialami siswa dalam memahami isi bacaan tersebut diduga sebagai akibat dari pelaksanaan pembelajaran yang konvesional. Di dalam pembelajaran konvensional, guru kurang membangkitkan skemata siswa sebelum membaca. Dikatakan demikian karena ketika disajikan suatu bahan bacaan, siswa tidak melakukan dan tidak dapat memahami dengan baik kegiatan prabaca (berkait dengan curah pendapat tentang topik yang akan dibaca). Oleh karena itu, siswa tidak memiliki pengetahuan awal yang dapat membantu memahami isi bacaan tersebut.

\section{Pembelajaran Membaca Kritis di Madrasah Ibtidaiyah}

Pembelajaran membaca kritis di tingkat sekolah dasar / Madrasah Ibtidaiyah seharusnya diberikan pada kelas lanjut. Dikatakan demikian karena siswa MI kelas lanjut di dalam dirinya sudah memungkinkan untuk berbagai tahapan operasional yang mengarah pada kegiatan berpikir normal dan abstrak. Pada tingkat MI kelas lanjut, siswa sudah mampu menganalisi dan memahami ide-ide, mampu berpikir logis tentang data-data ang abstrak., mampu menyusun hipotesis, dan mampu membangun konsep-konsep sederhana mengenai berbagai hal yang dipelajarinya.

Sehubunga dengan hal tersebut, perlu dipahami bahwa tahap pelaksanaan pembelajaran membaca kritis harus diawali dengan kegiatan pengelompokan dan klasifikasi tentang kondisi siswa yang pada kenyataannya berbeda sesuai dengan potensi dasar yang dimilikinya. Di dalam Kurikulum Berbasis Kompetensi $(\mathrm{KBK})$, dinyatakan bahwa perbedaan individu dapat diklasifikasikan menjadi tiga kelompok, yakni normal, sedang, dan tinggi. Tujuan diversifikasi tentang pengembangan siswa pada masing-masing kelompok di dalm kurikulum tersebut 
adalah (1) untuk kelompok normal; meengembangkan pemahaman tentang prinsip dan praktik aplikasi serta mengembangkan kemampuan praktik akademis yang berhubungan dengan kemampuan kerja, (2) untuk kelompok sedang: mengembangkan berbagai kemahiran (kemahiran berkomunikasi, kemahiran potensi diri, aplikasi praktik, kemahiran akademik, dan kemahiran praktik yang berhubungan dengan tuntutan dunia kerja ataupun demi kelanjutan program pendidikan profesional, dan (3) untuk kelompok tinggi; mengembangkan pemahaman tentang prinsip, teori, aplikasi, dan mengembangkan kemampuan akademik untuk memasuki pendidikan tinggi.

Penerapan Strategi SQ3R dalam Pembelajaran Membca Kritis Sastra di Madrasah Ibtidaiyah Kelas Lanjut

Bertumpu pada berbagai uraian di atas, tampak bahwa pemberian motivasi terhadap siswa dalam pembelajaran membaca kritis di kalangan siswa MI kelas lanjut merupakan sebuah tantangan tersebdiri bagi kalangan dunia pendidikan, khususnya guru. Oleh karena itu, sudah sewajarnya apabila para guru diharapkan mampu menemukan format dan pola pembelajaran Bahasa dan Sastra Indonesia yang lebih baru, manarik, dan menyenangkan agar pembelajaran dapat berlangsung kondusif. Apabila kondisi tersebut dapat terwujud, maka tidak mustahil para siswa akan semakin cinta dan bangga terhadap bahasa Indonesia.

Sebagai salah satu upaya untuk mnemukan model pembelajaran Bahasa dan sastra Indonesia yang terkait dengan kompetensi belajar membaca, maka penulis tertarik mengaji ulang tentang penerapan strategi SQ3R untuk meningkatkan kemampuan membaca kritis siswa sastra yang difokuskan pada siswa MI kelas lanjut.

Strategi SQ3R merupakan strategi pembelajaran membaca yang bertujuan untuk membantu pembaca agar dapat memahami secara utuh dan rinci tentang isi 
suatu teks. Dengan strategi SQ3R, pembaca akan lebih cepat menemukan gagasan-gagasan pokok yang terdapat di dalam teks. Langkah-langkah yang terdapat di dalam strategi SQ3R meliputi: survey, question, read, recite, and review. Langkah-langkah tersebut harus diterapkan secara berurutan agar tujuan yang ingin dicapai dalam membaca dapat tercapai (Eanes, 1997: 5-82). Masingmasing tahapan tersebut dapat diuraikan sebagai berikut.

Tahap Pengamatan (survey)

Pada tahap ini, siswa dituntut dapat menafsirkan makna judul cerpen, mengetahui biografi penulis, mengidentifikasi kata apayang dipakai untuk membahasakan diri penulis dalam cerpen, mengidentifikasi sudut pandang tokoh dalam penceritaan, menyebutkan tokoh-tokoh yag terlibat, dan menemukan peristiwa (awal, tengah, dan akhir) dari cerpen sekilas,

\section{Tahap Menyusun Pertanyaan (question)}

Pada tahap ini, siswa diminta membuat pertanyaan-pertanyaan yang berhubungan dengan menggunakan konsep pertanyaan $5 \mathrm{~W}+1 \mathrm{H}$.

Tahap Membaca (read)

Pada tahap ini, kegiatan siswa adalah membaca dalam hati secara keseluruhan dan menandai bagian-bagian cerpen yang menjadi jawaban atas pertanyaan yang telah dibuat. Sebagi tambahan, pada tahap ini sebenarnya terjadi tahap record, yakni siswa dituntut dapat mengidentifikasi penokohan, latar, alur, tema, nilai-nilai intrinsik cerpen.

Tahap Menceritakan Kembali (recite)

Pada tahap ini, siswa menceritakan kembali isi cerpen secara keseluruhan dengan menggunakan kata-kata sendiri.

Tahap Meninjau Ulang (review)

Pada tahap ini, siswa diminta untuk memeriksa dan meninjau kembali benar tidaknya catatan-catatan penting terkait dengan isi cerpen yang telah 
dibuatnya. Jika belum, maka siswa harus mencatat kembali kemudian mengaji kembali pekerjaan itu secara benar.

Kegitan di atas bersifat menyeluuh. Dikatakan demikian karena di dalam pembelajaran membaca kritis sastra dengan strategi SQ3R, siswa diharapkan mampu memngingat kembali isi cerpen yang telah dibacanyasecara keseluruhan. Apabila siswa tidak mampu melaksanakannya, maka siswa harus membaca kembali denga teliti catatn-catatan yang dibuatnya tentang isi cerpen tersebut. Hal ini dilaksanakan agarsiswa mampu mengomentari cerpen yang telah dibacanya.

Berdasarkan sedikit ilustrasi tersebut, tampak bahwa strategi SQ3R dalam pembelajaran membaca kritis sastra memang diperlukan. Dengan strategi SQ3R, siswa memiliki kebebasan dalam menganalisis cerpen. Siswa terangsang untuk mampu berpikir kritis terhadap permasalahan di sekitarnya. Staregi SQ3R melatih siswa untuk belajar secara kolaboratif dan kemampuan siswa dapat diukur berdasarkan hasil karya dan unjuk kerja.

Sebagai tambahan, perlu dipahami bahwa pembelajaran membaca di sekolah dasar meripakan salah satu pmbelajaran yang esensial. Sebagai contoh, di dalam GBPP 1994, dinyatakan bahwa tujuan pelajaran membaca untukkelas enam (kelas lanjut) adalah (1) siswa memahami isi wacana secara garis besar dan memberikan tanggapan yang dibaca dan didengar; (2) siswa mampu mendapatkan informasi dari berbagai bahan tertulis atau lisan (pengetahuan, gagasan, pendapat, permasalahan, pesan, ungkapan perasaan, pengalaman dan peristiwa); (3) siswa mampu mendapatkan data maupun fakta dari buku-buku dan memanfaatkannya untuk berbagai keperluan (Depdikbud, 1993: 4). Sebagai upaya untuk mencapai tujuan tersebut, sebelumya guru dituntut mampu memahami prinip=prinsip membaca dan cara mengajarkannya kepada siswa.

Fakta-fakta tentang rendahnya kemampuan siswa di dalam memahami isi bacaan (cerpen) antara lain diduga disebabkan oleh kurang tepatnya strategi 
pembelajaran yang dipilih dan diterapkan oleh guru, dalam hal ini khususnya strategi pembelajaran membaca kristis sastra. Dengan perkataan lain, guru kurang memiliki kemampuan untuk melakukan inovasi dalam pembelajaran. Sebab utamanya adalah guru kurang memiliki pengetahuan dan kurangnya pemahaman tentang berbagai strategi pembelajaran (diantaranya strategi pembelajaran membaca kritis). Sehubungan dengan hal itu, strategi SQ3R merupakan salah satu strategi dalam membaca yang bertujuan untuk membantu pembaca memahami ecara utuh dan rinci tentang isi suatu teks. Dengan strategi SQ3R, pembaca akan lebih cepaat menemukan gagasan-gagasan pokok yang ada dalam teks (Eanes, 1997: 5-82).

\section{analisis pelaksanaan pembelajaran dengan strategi SQ3R dari aspek guru}

\begin{tabular}{|c|c|c|}
\hline $\begin{array}{c}\text { tahap } \\
\text { pembelajaran }\end{array}$ & Aspek & langkah-langkah \\
\hline Survey & $\begin{array}{l}\text { guru membuka } \\
\text { pelajaran } \\
\text { guru membangkitkan } \\
\text { skemata siswa terkait } \\
\text { dengan bahan bacaan }\end{array}$ & $\begin{array}{l}\text { menyampaikan tujuan pembelajaran } \\
\text { menjelaskan tugas-tugas belajar } \\
\text { membagi tugas dalam kelompok } \\
\text { curah pendapat untuk } \\
\text { membangkitkan skemata siswa } \\
\text { menampilan gambar dan topik } \\
\text { cerpen dan meminta siswa untuk } \\
\text { menuliskan pengetahuan yang } \\
\text { dimiliki yang berhubungan dengan } \\
\text { gambar dan topik } \\
\text { meminta siswa utuk }\end{array}$ \\
\hline
\end{tabular}

334 | http://journal.unesa.ac.id/index.php/paramasastra 
Dwi Masdi Widada, Implementasi Strategi SQ3R... (hIm. 323-339)

\begin{tabular}{|c|c|c|}
\hline & $\begin{array}{l}\text { guru memprediksi isi } \\
\text { bacaan }\end{array}$ & $\begin{array}{l}\text { mengidentifikasi sudut pandang } \\
\text { tokoh dalam cerita } \\
\text { memprediksi isi cerpen berdasarkan } \\
\text { gambar yang ditampilkan guru }\end{array}$ \\
\hline Question & $\begin{array}{l}\text { guru membimbing } \\
\text { siswa membuat } \\
\text { pertanyaan tentang apa } \\
\text { yang ingin diketahu } \\
\text { dari cerpen }\end{array}$ & $\begin{array}{l}\text { membimbing siswa untuk } \\
\text { memprediksi isi cerpen dalam } \\
\text { bentuk kalimat tanya } \\
\text { meminta siswa untuk menuliskan } \\
\text { infomasi yang diketahui pda kolom } \\
\text { record }\end{array}$ \\
\hline read \& record & $\begin{array}{l}\text { guru mengarahkan } \\
\text { siswa membaca dalam } \\
\text { hati dan mengerjakan } \\
\text { tugas } \\
\text { guru membimbing } \\
\text { siswa untuk } \\
\text { menuliskan hal-hal } \\
\text { penting tetang isi } \\
\text { cerpen }\end{array}$ & $\begin{array}{l}\text { membagikan teks bacaan dan LKS } \\
\text { meminta siswa membaca dalam hati } \\
\text { memberi bimbingan pada siswa } \\
\text { dalam mengerjakan tugas dan } \\
\text { menjawab pertanyaan yang ditulis } \\
\text { dalam kolom record } \\
\text { membimbing siswa untuk } \\
\text { menuliskan informasi yang telah } \\
\text { diperolehnya dari membaca } \\
\text { membimbing siswa untuk } \\
\text { memetakan informasi yang telah } \\
\text { diperolehnya } \\
\text { meminta siswa untuk memeriksa } \\
\text { kembali pertanyaan yang ditulis di } \\
\text { kolom record }\end{array}$ \\
\hline
\end{tabular}




\begin{tabular}{|l|l|l|}
\hline & & $\begin{array}{l}\text { meminta siswa membuat } \\
\text { kesimpulan }\end{array}$ \\
\hline Recite & $\begin{array}{l}\text { guru meminta siswa } \\
\text { menceritakan kembali } \\
\text { isi cerpen dengan kata- } \\
\text { kata sendiri }\end{array}$ & $\begin{array}{l}\text { meminta siswa untuk } \\
\text { mempresentasikan hasil kerja } \\
\text { meminta siswa untuk menanggapi } \\
\text { hasil presentasi }\end{array}$ \\
\hline Review & $\begin{array}{l}\text { guru memantapkan } \\
\text { pemahaman terhadap } \\
\text { cerpen }\end{array}$ & $\begin{array}{l}\text { mengadakan refleksi untuk } \\
\text { memantapkan pemahaman siswa } \\
\text { terhadap materi yang telah dipeajari }\end{array}$ \\
\hline
\end{tabular}

analisis pelaksanaan pembelajaran dengan strategi SQ3R dari aspek siswa

\begin{tabular}{|l|l|l|}
\hline \multicolumn{1}{|c|}{$\begin{array}{c}\text { tahap } \\
\text { pembelajaran }\end{array}$} & \multicolumn{1}{|c|}{ Aspek } & \multicolumn{1}{c|}{ langkah-langkah } \\
\hline \multirow{5}{*}{ survey } & $\begin{array}{l}\text { siswa memperhatikan } \\
\text { penjelasan guru }\end{array}$ & $\begin{array}{l}\text { memperhatikan penjelasan guru } \\
\text { tentang tugas dan proses } \\
\text { pembelajaran }\end{array}$ \\
& $\begin{array}{l}\text { siswa mengingat } \\
\text { kembali pengatahuan } \\
\text { yang dimilikinya } \\
\text { berhubungan dengan } \\
\text { gambar dan topik }\end{array}$ & $\begin{array}{l}\text { mengamati dan menafsirkan makna } \\
\text { gambar dan judul cerpen yang } \\
\text { ditampilkan guru } \\
\text { menuliskan informasi yang } \\
\text { berhubungan dengan gambar dan } \\
\text { topik }\end{array}$ \\
\hline
\end{tabular}

336 | http://journal.unesa.ac.id/index.php/paramasastra 
Dwi Masdi Widada, Implementasi Strategi SQ3R... (hIm. 323-339)

\begin{tabular}{|c|c|c|}
\hline & memprediksi isi cerpen & $\begin{array}{l}\text { mengidentifikassi sudut pandang } \\
\text { tokoh } \\
\text { memprediksi isi bacaan berdasrkan } \\
\text { gambar dan topik cerpen }\end{array}$ \\
\hline Question & $\begin{array}{l}\text { membuat kalimat tanya } \\
\text { tentang cerpen } \\
\text { berdasarkan prediksi } \\
\text { yang dibuat }\end{array}$ & $\begin{array}{l}\text { membuat kalimat tanya tentang isi } \\
\text { cerpen berdasarkan prediksi } \\
\text { menulis informasi yang ingin } \\
\text { diketahui dalam bentuk kalimat } \\
\text { tanya pada lembaar kerja }\end{array}$ \\
\hline read \& record & $\begin{array}{l}\text { membaca dalam hati } \\
\text { menuliskan hal-hal } \\
\text { yang penting untuk } \\
\text { membuat kesimpulan } \\
\text { tentang isi cerpen }\end{array}$ & $\begin{array}{l}\text { menerima teks bacaan dan LKS } \\
\text { membaca dalam hati } \\
\text { memahami isi cerpen dan menandai } \\
\text { hal-hal yang penting dari isi cerpen } \\
\text { menuliskan informsi yang telah } \\
\text { diperolehnya setelah membaca pada } \\
\text { lembar kerja } \\
\text { memetakan informasi yang telah } \\
\text { diperolehnyake dalam kategori } \\
\text { menjawab pertanyaan yang telah } \\
\text { dibuat sebelumnya } \\
\text { membuat kesimpulan tentang isi } \\
\text { cerpen }\end{array}$ \\
\hline Recite & $\begin{array}{l}\text { meminta siswa } \\
\text { menceritakan kembali } \\
\text { isi cerpen dengan kata- }\end{array}$ & $\begin{array}{l}\text { mempresentasikan hasil kerja } \\
\text { menanggapi dari beberapa }\end{array}$ \\
\hline
\end{tabular}




\begin{tabular}{|l|l|l|}
\hline & kata sendiri & petanyaan \\
\hline Review & memantapkan & refleksi untuk memantapkan \\
pemahaman terhadap & pemahaman terhadap materi yang \\
cerpen & tlah dipelajarinya \\
& mengerjakan evaluasi yang \\
& & diberikan guru pembimbing \\
\hline
\end{tabular}

\section{SIMPULAN}

Berdasarkan uraian tentang penerapan strategi SQ3R dalam membaca kritis sastra dapat disimpulkan bahwa sebagai upaya untuk mencapai tujuan dari proses pembelajaran membaca kritis, guru perlu membuat perencanaan proses pembelajaran. Hal tersebut perlu dilakukan agar pelaksanaan pembelajaran membaca kritis sastra dapat berjalan lebih terarah.

Dalam upaya meningkatkan kemampuan membaca kritis sastra, guru perlu menjelaskan terlebih dahulu tentang tujuan pembelajaran, membangkitkan skemata siswa yan terkait dengan topik, membimbing siswa dalam prose menemukan pokok pikiran, dan memantapkan pemahaman siswa terhadap bahan bacaandan mengadakan evaluasi.

Penerapan strategi pembelajaran yang dilandasi dengan pengajian secara ilmiah akan dapat membangkitkan skemata pemikiran siswa sehingga dapat menunjang ketercapaian tujuan dan ketuntasan belajar.

SQ3R merupakan strategi belajar yang efektif, namun ini tidak berlaku bagi semua siswa. Pengenalan terhadap beragam variasi strategi merupakan hal penting bagi siswa yakni pengenalan berbagai strategi yang dapat mengembangkan kesadaran metakognitif mereka. 
Dwi Masdi Widada, Implementasi Strategi SQ3R... (hlm. 323-339)

\section{DAFTAR PUSTAKA}

Burns, Paul C. Betty D. Roe Elinor P. Ross. 1996. Teaching Reading in Today's Elementery Schools. Boston: Houghton Mifflin Company.

De Porter, Bobbi \& Mike Hernacki. 1992. Quantum learning: Unleshing The Genius In You. New York. Dell Publishing.

Depdikbud. 1993. Kurikulum: Garis-garis Besar Program Pengajaran Bahasa Indonesia SLTP. Jakarta: Depdikbud.

Depdiknas. 1992. Membaca Bahan Pelatihan Terintegrasi Berbasis Kompetensi Guru Mata Pelajaran Bahasa Indonesia. Jakarta: Dirjen Dikdasmen.

Depdiknas. 2003. Kurikulum 2004. Jakarta: Depdiknas.

Depdiknas. 2003. Pedoman Khusus Pengembangan Silabus dan Penilaian. Jakarta: Depdiknas.

Eanes, Robin. 1997. Content Are Literary: Teaching fot Today and Tomorrow. Albany, NY: Delmar Publisher.

Harris, Larry \& Smith Carl B. 1986. Reading Intruction, Diacnostic Teaching in the Class Room. New York. MacMillan Publisher Company.

Sidi, Idra Djati. 2001. Menuju Masyarakat Belajar. Jakarta: Paramadina.

Syafi'ie. 1993. Terampil Berbahasa Indonesia I. Jakarta: Depdiknas. 